\title{
Performance of a Passive Feedlot Runoff Control and Treatment System
}

\author{
B. L. Woodbury, J. A. Nienaber, R. A. Eigenberg
}

\begin{abstract}
The recent signing of the NPDES permit regulations and effluent limitations guidelines for CAFO has generated much interest from smaller beef cattle feeding operations for a more cost-effective solution for managing feedlot runoff. A passive runoff control and treatment system was constructed to reduce long-term liquid storage, provide solids separation, and evenly distribute the liquid discharge for grass hay production. The overall objective of this study was to evaluate the effectiveness of this passive system for reducing contaminant discharge. The system effectively reduced the cumulative mass of total and volatile suspended solids and reduced chemical oxygen demand by 80\%, 67\%, and 59\%, respectively. Significant reductions of these constituents in the runoff water as it passed through the system were measured for most precipitation events. No water was measured exiting the vegetative filter strip during the three-year period of this study. Therefore, the discharge water was effectively contained and used for hay crop production. Estimated total nitrogen (TN) load in the discharge water entering the vegetative filter strip was equivalent to or less than the TN removed by the crop. System robustness was demonstrated during feedlot pen renovation when significant reductions in contaminant concentrations were measured for most all precipitation events during that period.
\end{abstract}

Keywords. Animal waste management, Feedlot runoff control, Nutrient management, Waste treatment.

$\mathrm{O}$ n December 15, 2002, the Environmental Protection Agency issued a Final Rule on NPDES Permit Regulations and Effluent Limitations Guidelines for Confined Animal Feeding Operations (CAFO) (40 CFR Parts 9, 122, 123, and 412; EPA, 2003). Specified in this regulation (40 CFR Part 412, EPA, 2003) is the requirement for CAFO to use the best practical control technology currently available to contain all runoff resulting from a 25-year, 24-hour rainfall event. It is generally accepted that traditional retention ponds are the best practical control technology. However, a site-specific alternative system can be permitted if it meets performance standards (40 CFR Part 412; EPA, 2003).

One of the obstacles for CAFOs, particularly for smaller operations, will be meeting these NPDES regulations. Proven traditional structures like retention ponds are expensive to construct, difficult to maintain, and may require specialized equipment to manage. An additional problem resulting from retention ponds is the potential for groundwater contamination resulting from seepage (McCullough et al., 1999; Parker et al., 1999; Huffman and Westerman, 1995; Westerman et al., 1995).

Woodbury et al. (2002) evaluated construction and operation of a passive runoff control and treatment system

Article was submitted for review in June 2002; approved for publication by the Soil \& Water Division of ASAE in September 2003. Presented at the 2002 ASAE Annual Meeting as Paper No. 022267.

The authors are Bryan L. Woodbury, ASAE Member Engineer, Research Scientist, John A. Nienaber, ASAE Member Engineer, Agricultural Engineer, and Roger A. Eigenberg, ASAE Member, Agricultural Engineer, USDA-ARS U.S. Meat Animal Research Center, Clay Center, Nebraska.Corresponding author: Dr. Bryan Woodbury, USDA-ARS U.S. Meat Animal Research Center, P.O. Box 166, Clay Center, NE 68933; phone: 402-762-4275; fax: 402-762-4273; e-mail: woodbury@email.marc.usda.gov. designed to reduce the volume of long-term liquid storage, provide adequate solids separation, and evenly distribute basin discharge water for grass hay production. They concluded that the passive system demonstrated very good solids separation, with minimal time required for operation and maintenance. In addition, operation and maintenance requirements were accomplished using equipment typical to CAFOs.

However, Woodbury et al. (2002) did not report the performance of the passive system for contaminant reduction. Therefore, the overall objective of this study was to evaluate the effectiveness of this passive feedlot runoff control and treatment system for reducing contaminant discharge. The specific objectives were: (1) to evaluate the solids removal from pen runoff water as it passed through a gravity-drained debris basin, and (2) to evaluate basin discharge water and nutrient usage by a vegetative filter strip (VFS).

\section{Material AND Methods}

Details concerning the construction and instrumentation of the passive runoff control and treatment system can be found in Woodbury et al. (2002). However, a brief description is included. Eight pens $(30 \times 90 \mathrm{~m}$ each $)$ at the Meat Animal Research Center (Clay Center, Neb.) feedlot were selected. These pens were stocked with 70 to 80 head per pen of finishing cattle for approximately 180-day cycles.

The design components of the system included a grass approach, a terrace with a debris basin, and a VFS (fig. 1). A $300 \mathrm{~m}$ long flat-bottom debris basin and terrace was constructed to provide a 5 to $8 \mathrm{~min}$ hydraulic retention time for solid separation (fig. 2). Thirteen $20 \mathrm{~cm}$ Ultra Rib PVC storm discharge pipes were installed through the terrace at $21 \mathrm{~m}$ 


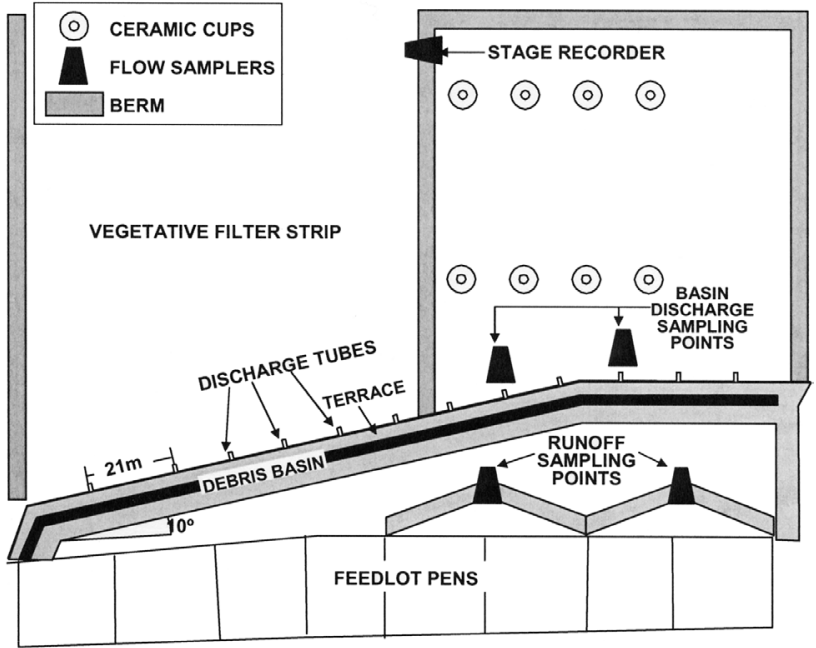

Figure 1. Plan view showing the relationship of the feedlot pens, debris basin with terrace, discharge tubes, and the vegetative filter strips. Note the addition of the flow samplers, ceramic cups, and berms for isolation of the instrumented section of the vegetative filter strip.

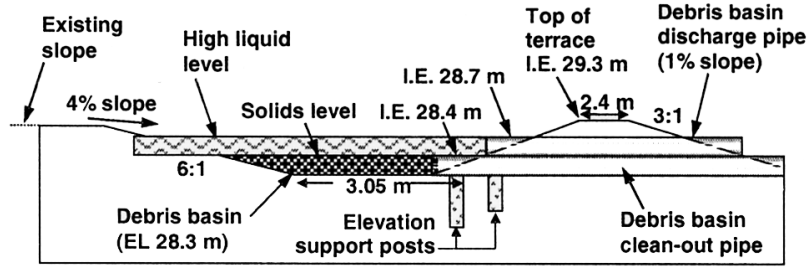

Figure 2. Schematic cross-sectional diagram of the debris basin, terrace, discharge tubes, and drain tubes.

intervals. These pipes were installed at the same elevation to provide uniform distribution of debris basin discharge water across the VFS for nutrient and water utilization (fig. 2). The 6.0 ha bromegrass VFS was adjacent and downslope along the length of the basin, and ranged from 200 to $210 \mathrm{~m}$ in width at a slope of approximately $0.5 \%$ (fig. 1). The size of the VFS was based on the expected nutrient load estimated by the Nutrient Fate Model for Beef Cattle Feedlots (Eigenberg et al., 1998).

Two sets of berms were established to direct runoff from two adjacent pens through one of two $0.23 \mathrm{~m}$ Parshall flumes (fig. 1). Samplers were installed at each flume to characterize water quality. Two additional $0.15 \mathrm{~m}$ Parshall flumes, with samplers, were installed down-gradient from discharge tubes to collect samples. Difficulties of maintaining upstream flow resulted in using the NRCS curve number method to estimate runoff volume (Grant, 1991). Samplers were operated in the field from April 1 to October 31 annually. Very little runoff occurred during the 5-month period without samplers primarily due to frozen conditions.

Berms were constructed at the down-gradient end and along the sides of the VFS to isolate it from the surrounding environment (fig. 1). A portion of the VFS was divided with a berm, such that runoff from the four pens was isolated (fig. 1). At the down-gradient end of this section, a $0.15 \mathrm{~m}$ Parshall flume was installed and instrumented with a stage recorder to measure any runoff leaving the VFS (fig. 1). Soil water sampling ceramic cups were placed throughout the VFS at a depth of $1.8 \mathrm{~m}$ (fig. 1).

Hay was harvested using conventional wind rowing and bailing equipment. Multiple vegetative samples were col-
Table 1. Chemical and physical composition of basin ${ }^{[a]}$ solids, and dry matter and total nitrogen removed by the hay crop.

\begin{tabular}{|c|c|c|c|c|c|c|}
\hline \multirow[b]{2}{*}{ Year } & \multirow[b]{2}{*}{$\begin{array}{c}\text { Total } \\
\text { Solids, } \\
\text { Dry } \\
(\mathrm{kg})\end{array}$} & \multirow[b]{2}{*}{$\begin{array}{c}\text { Volatile } \\
\text { Solids } \\
\text { (kg) }\end{array}$} & \multirow[b]{2}{*}{$\begin{array}{l}\text { Total } \\
\mathrm{N} \\
(\mathrm{kg})\end{array}$} & \multirow[b]{2}{*}{$\begin{array}{c}\text { Organic } \\
\mathrm{N} \\
(\mathrm{kg})\end{array}$} & \multicolumn{2}{|c|}{ Hay Crop } \\
\hline & & & & & $\begin{array}{l}\text { Dry } \\
\text { Matter } \\
\text { (kg) }\end{array}$ & $\begin{array}{c}\text { Total } \\
\mathrm{N} \\
(\mathrm{kg})\end{array}$ \\
\hline 1997 & 67,000 & NA & NA & NA & NA & NA \\
\hline 1998 & 49,500 & NA & NA & NA & NA & NA \\
\hline 1999 & 98,000 & 14,500 & 450 & 380 & NA & NA \\
\hline 2000 & 37,100 & 5,900 & 180 & 150 & 32,760 & 700 \\
\hline 2001 & 54,400 & 9,400 & 310 & 280 & 25,100 & 420 \\
\hline
\end{tabular}

lected from the wind rows across the VFS just prior to bailing. Samples were analyzed for dry matter and TN (combustion analysis, Model CN 2000, Leco Corp., St. Joseph, Mich.). Mass of harvested dry matter hay was recorded and used to determine the mass of $\mathrm{TN}$ removed.

Rain events were measured during the 1999 through 2001 seasons (table 1). These events were measured by the High Plains Regional Climate Center (site number 251684), located approximately $2 \mathrm{~km}$ east-northeast of the research site. Runoff volumes for each rain event were estimated using the NRCS runoff curve method. These values were used with the averaged runoff and discharge concentrations to determine the mass of total suspended solids (TSS), volatile suspended solids (VSS), chemical oxygen demand (COD), and total nitrogen (TN) entering and exiting the debris basin. The mass of TN exiting the debris basin was considered the amount entering the VFS.

Runoff and debris basin discharge samples were frozen until analyses could be completed. Total solids were determined gravimetrically at $105^{\circ} \mathrm{C}$, while volatile solids were determined by loss on ignition at $550^{\circ} \mathrm{C}$. These analyses follow Standard Methods 2540C and 2540E, respectively (APHA, 1992). Chemical oxygen demand was determined using Standard Method 5220 (APHA, 1992). Total nitrogen was determined by combining analyses from a modified total Kjeldahl nitrogen procedure with a cadmium-reduction nitrate-nitrogen analysis. These procedures follow methods 10072 and 10020 outlined in the Hach Water Analysis Handbook (Hach, 1992).

Analysis of the solids removed from the debris basin consisted of total and volatile solids, TN, and organic nitrogen. Total solids were determined gravimetrically at $105^{\circ} \mathrm{C}$, while volatile solids were determined by loss on ignition at $550^{\circ} \mathrm{C}$. Total nitrogen was approximated by summing the total Kjeldahl nitrogen with the nitrate-nitrogen $(2 M \mathrm{KCl}$ extraction, colorimetric determination) (Mulvaney, 1996). Organic nitrogen was determined by adjusting the total Kjeldahl nitrogen for ammonium.

\section{Results AND Discussion}

Solids from the debris basin were removed and analyzed during the summers of 1999 through 2001 (table 1). The total mass of dry solids deposited in the basin varied from a high of $98,000 \mathrm{~kg}$ for 1999 to a low of $37,100 \mathrm{~kg}$ for the following year. When averaged over the 1999 through 2001 season, approximately $16 \%$ of solids deposited in the debris basin were volatile (table 1). Approximately $86 \%$ of the nitrogen 
Table 2. Predicted runoff and contaminant loads for each measured rainfall event.

\begin{tabular}{|c|c|c|c|c|c|c|c|c|c|c|}
\hline \multirow[b]{2}{*}{ Date } & \multirow[b]{2}{*}{$\begin{array}{c}\text { Rainfall } \\
(\mathrm{mm})\end{array}$} & \multirow{2}{*}{$\begin{array}{c}\text { Estimated } \\
\text { Pen } \\
\text { Runoff[a] } \\
\left(\mathrm{m}^{-3}\right)\end{array}$} & \multicolumn{2}{|c|}{ TSS } & \multicolumn{2}{|c|}{ VSS } & \multicolumn{2}{|c|}{ COD } & \multicolumn{2}{|c|}{$\mathrm{TN}$} \\
\hline & & & $\begin{array}{c}\text { Pen } \\
\text { Runoff } \\
(\mathrm{kg})\end{array}$ & $\begin{array}{c}\text { Basin } \\
\text { Discharge } \\
(\mathrm{kg})\end{array}$ & $\begin{array}{c}\text { Pen } \\
\text { Runoff } \\
(\mathrm{kg})\end{array}$ & $\begin{array}{c}\text { Basin } \\
\text { Discharge } \\
(\mathrm{kg})\end{array}$ & $\begin{array}{c}\text { Pen } \\
\text { Runoff } \\
(\mathrm{kg})\end{array}$ & $\begin{array}{c}\text { Basin } \\
\text { Discharge } \\
(\mathrm{kg})\end{array}$ & $\begin{array}{c}\text { Pen } \\
\text { Runoff } \\
(\mathrm{kg})\end{array}$ & $\begin{array}{c}\text { Basin } \\
\text { Discharge } \\
(\mathrm{kg})\end{array}$ \\
\hline \multicolumn{11}{|l|}{1999} \\
\hline June 22 & 59 & 740 & 1870 & 390 & 660 & 320 & 4640 & 3050 & 89 & 48 \\
\hline June 27 & 25 & 120 & 1050 & 50 & 110 & 20 & 890 & 450 & 26 & 12 \\
\hline June 28 & 18 & 70 & 490 & 20 & 40 & 40 & 520 & 400 & 13 & 2 \\
\hline Aug. 6 & 39 & 320 & 1910 & 0 & 90 & 0 & 1860 & 0 & 55 & 0 \\
\hline Aug. 17 & 25 & 120 & 600 & 60 & 220 & 30 & 860 & 680 & 20 & 5 \\
\hline Totals & 166 & 1350 & 5920 & 520 & 1120 & 410 & 8770 & 4580 & 202 & 67 \\
\hline \multicolumn{11}{|l|}{2000} \\
\hline May 26 & 38 & 300 & 1300 & 460 & 1020 & 110 & 3390 & 180 & 67 & 71 \\
\hline June 12 & 30 & 180 & 670 & 320 & 340 & 70 & 2210 & 100 & 37 & 40 \\
\hline June 20 & 56 & 670 & 3860 & 1160 & 850 & 340 & 1160 & 220 & 94 & 44 \\
\hline June 26 & 53 & 610 & 2010 & 1200 & 920 & 140 & 1340 & 290 & 98 & 43 \\
\hline July 5 & 100 & 1830 & 4360 & 370 & 2950 & 370 & 1430 & 470 & 289 & 139 \\
\hline Aug. 19 & 41 & 350 & 2700 & 120 & 130 & 20 & 550 & 30 & 45 & 25 \\
\hline Totals & 318 & 3940 & 14,900 & 3630 & 2740 & 1050 & 10,080 & 1290 & 630 & 361 \\
\hline \multicolumn{11}{|l|}{2001} \\
\hline May 4 & 69 & 990 & 7300 & 1490 & 2220 & 490 & 6680 & 4080 & 307 & 233 \\
\hline May 29 & 63 & 830 & 1570 & 500 & 1120 & 190 & 3290 & 1590 & 164 & 95 \\
\hline May 30 & 46 & $880^{[\mathrm{b}]}$ & 3270 & 510 & 940 & 510 & 4510 & 2880 & 165 & 59 \\
\hline June 4 & 20 & $200^{[b]}$ & 430 & 0 & 160 & 0 & 980 & 0 & 36 & 0 \\
\hline July 5 & 32 & 210 & 570 & 100 & 260 & 150 & 1080 & 300 & 45 & 10 \\
\hline July 28 & 17 & 60 & 140 & 0 & 80 & 0 & 430 & 0 & 12 & 0 \\
\hline Sept. 16 & 42 & 380 & 1580 & 230 & 330 & 180 & 2430 & 830 & 69 & 36 \\
\hline Totals & 289 & 3550 & 14,860 & 2830 & 5110 & 1520 & 19,400 & 9680 & 798 & 432 \\
\hline
\end{tabular}

[a] Values determined using NRCS curve number 85 for pen surfaces and 58 for grass surface assuming AMC II.

[b] Values determined using NRCS curve number 93 for pen surfaces and 76 for grass surfaces assuming AMC III.

Zero values indicate no measured discharge volume.

deposited in the basin was in the organic form. The overall TSS, VSS, and COD removal within the basin for the three years of the study averaged $80 \%, 67 \%$, and $59 \%$, respectively (table 2).

Two seasons of hay crop were removed from the VFS. There were $32,760 \mathrm{~kg}$ of dry matter removed during the 2000 season (table 1). This dry matter contained $700 \mathrm{~kg}$ of TN (table 1). When compared with the estimated $361 \mathrm{~kg}$ TN added by the debris basin discharge water, there was a net removal of $339 \mathrm{~kg}$ of TN from the VFS (table 1 and 2). During the 2001 season, $25,100 \mathrm{~kg}$ dry matter was harvested during late summer, containing $420 \mathrm{~kg}$ of TN (table 1). A $12 \mathrm{~kg}$ net gain of TN in the VFS occurred when compared with the addition of TN by the discharge water (tables 1 and 2).

There were four measured rain events that resulted in collected runoff and discharge samples during the 1999 season (table 2). The $39 \mathrm{~mm}$ event that occurred on August 6 resulted in runoff and discharge water, but equipment failure prevented collection of discharge water. The largest storm event was a $59 \mathrm{~mm}$ rainfall that occurred on June 22. This event was part of a week-long storm series that resulted in a total $102 \mathrm{~mm}$ of rainfall. These events generated an estimated $1350 \mathrm{~m}^{3}$ of runoff containing 5920, 1120, and 8770 $\mathrm{kg}$ of TSS, VSS, and COD, respectively (table 2). Discharge from the debris basin contained 520,410 , and $4580 \mathrm{~kg}$ of TSS, VSS, and COD, respectively (table 2). This resulted in a 5.3 TSS/VSS ratio for the runoff and a 1.3 TSS/VSS ratio for the discharge water. The concentrations of TSS in the runoff water ranged from $2530 \mathrm{mg} \mathrm{L}^{-1}$ to $8500 \mathrm{mg} \mathrm{L}^{-1}$, while the discharge concentrations ranged between 400 and $520 \mathrm{mg}$ $\mathrm{L}^{-1}$ (fig. 3). The lowest runoff TSS concentration occurred during the largest rainfall event due to dilution of the highly erodible solids load, which occurred early in the runoff event. In addition, there was significant $(\mathrm{p}=0.05)$ removal of TSS for all rainfall events during the 1999 season (fig. 3).

Runoff VSS concentrations during the 1999 season ranged from 530 to $1810 \mathrm{mg} \mathrm{L}^{-1}$ (fig. 4). The discharge VSS concentrations ranged from 200 to $590 \mathrm{mg} \mathrm{L}^{-1}$ (fig. 4). It should be noted that little or no reduction in VSS concentration was measured during the rainfall event on June 28. This event was relatively small and occurred at the end of a week-long series of rainfall events. Therefore, most of the highly erodible solids had already been removed by earlier storms, and this runoff contained fewer carbonate complexes from the pen surface. Some of these complexes can be volatilized at the combustion temperature of the analysis. The runoff COD concentrations during the 1999 season ranged from 6280 to $7920 \mathrm{mg} \mathrm{L}^{-1}$, while the discharge ranged from 3690 to $6060 \mathrm{mg} \mathrm{L}^{-1}$ (fig. 5). There were significant reductions $(\mathrm{p}=0.05)$ between the runoff and discharge concentration for all measured precipitation events (fig. 5).

A major renovation of the feedlot pens was initiated on May 20, 2000. Renovation included dismantling pens, removing feed bunks, and reshaping the feedlot surface. The renovation took approximately three months to complete. The samplers and runoff control structures were minimally affected by the renovation, so it was decided to continue the study to evaluate the impact on performance. 

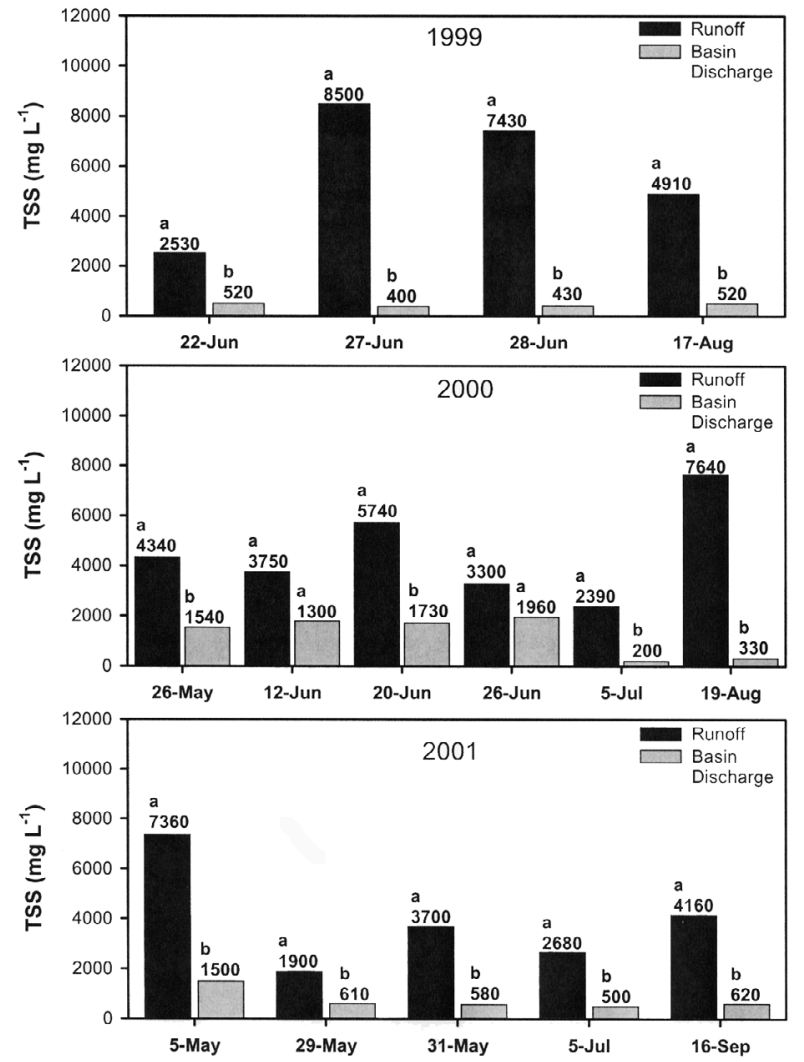

Figure 3. Total suspended solids concentrations of the runoff and discharge water during the measured precipitation events. Letters represent differences at the 0.05 level.

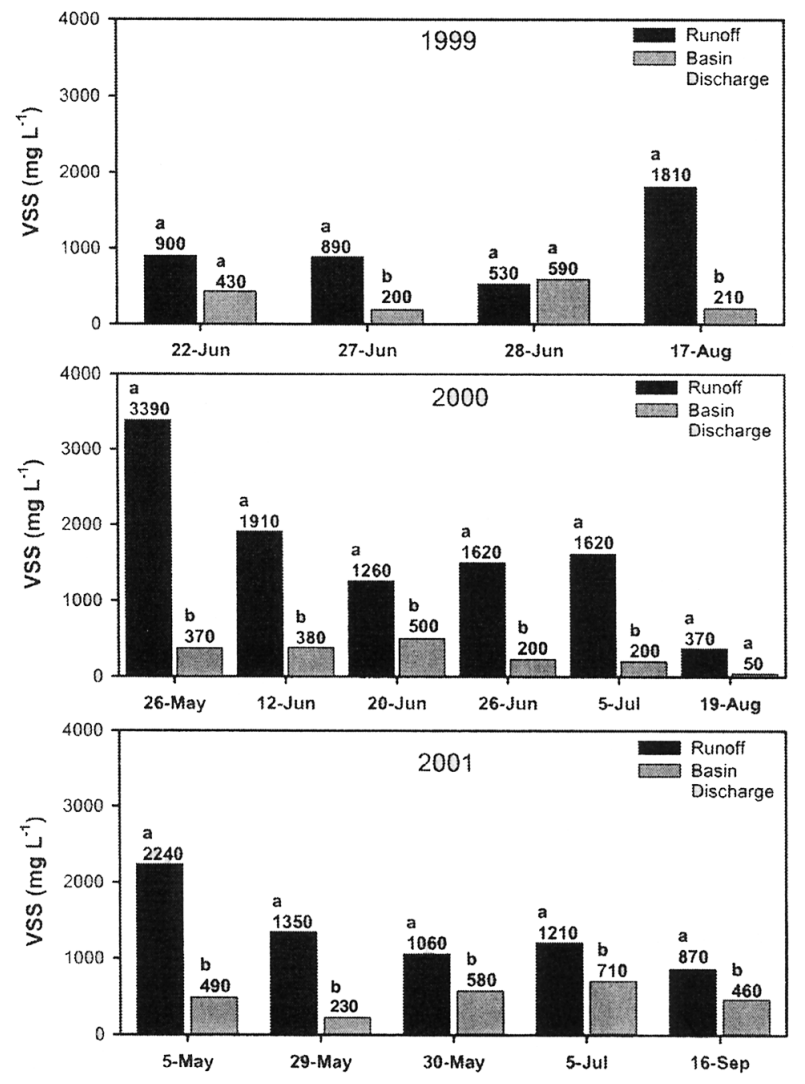

Figure 4. Volatile suspended solids concentrations of the runoff and discharge water during measured precipitation events. Letters represent differences at the 0.05 level.
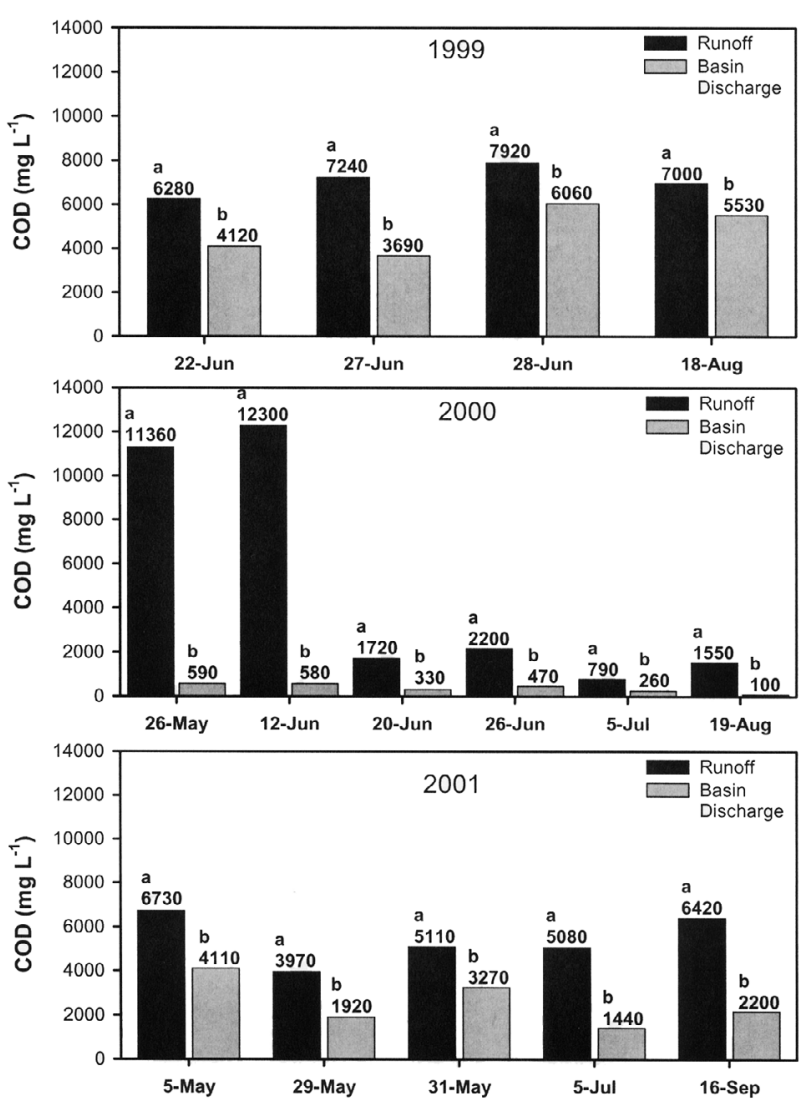

Figure 5. Chemical oxygen demand concentrations of the runoff and discharge water during the measured precipitation events. Letters represent differences at the 0.05 level.

Six measured rain events resulted in collected runoff and discharge samples during the 2000 season (table 2). The largest storm event was a $100 \mathrm{~mm}$ rainfall that occurred on July 5. These events resulted in $3940 \mathrm{~m}^{3}$ of runoff that contained 14900, 2740, and $10080 \mathrm{~kg}$ of TSS, VSS, and COD, respectively (table 2). The discharge contained 3630, 1050 , and $1290 \mathrm{~kg}$ of TSS, VSS, and COD, respectively (table 2). This resulted in a 5.4 TSS/VSS ratio for the runoff and a 3.5 TSS/VSS ratio for the discharge water. Concentrations of TSS in the runoff water ranged from $2390 \mathrm{mg} \mathrm{L}^{-1}$ to $7640 \mathrm{mg} \mathrm{L}^{-1}$ (fig. 3). It was expected that these values would reflect the construction process and be much greater. Barriers preventing cross-pen flow were removed during the construction process. This compromised the collection and direction of the runoff through the flumes. Discharge concentrations ranged between 200 and $1960 \mathrm{mg} \mathrm{L}^{-1}$, with four of the six events having concentrations greater that 1500 $\mathrm{mg} \mathrm{L}^{-1}$ (fig. 3). These values appear to reflect the construction process. Regardless of the operational problems, there were significant $(\mathrm{p}=0.05)$ reductions in TSS concentrations for rainfall events as the runoff passed through the system.

Runoff VSS concentrations during the 2000 season ranged from 370 to $3390 \mathrm{mg} \mathrm{L}^{-1}$ (fig. 4). The highest VSS concentration resulted on May 26, shortly after the construction process began. The relatively high concentrations that persisted throughout the season reflected disturbance of the organic surface layer and mound during the early part of the renovation. Discharge VSS concentrations ranged from 50 to $500 \mathrm{mg} \mathrm{L}^{-1}$ (fig. 4). It should be noted that significant ( $\mathrm{p}=$ 0.05 ) reductions in VSS concentration as the runoff passed 
though the system were measured, with the exception of an event on August 19.

Runoff COD concentrations during the 2000 season ranged from 790 to $12,300 \mathrm{mg} \mathrm{L}^{-1}$ (fig. 5). The first two rain events appeared to pick up the organic matter disturbed during the renovation of the mound and pen surfaces. After these two events, the runoff COD concentrations were approximately $1 / 3$ the average concentration measured during the 1999 season. The discharge COD concentrations ranged from 100 to $590 \mathrm{mg} \mathrm{L}^{-1}$ (fig. 5). These values were much lower than the previous season. This indicates that the disturbed organic matter was settlable.

Five measured rain events resulted in collected runoff and discharge samples during the 2001 season (table 2). Two events initiated runoff sample collection but were not sufficient to initiate discharge sample collection. The largest storm event was a two-day event that resulted in $109 \mathrm{~mm}$ of precipitation. The season-long cumulative totals resulted in $3550 \mathrm{~m}^{3}$ of runoff that contained 14860,5110 , and $19400 \mathrm{~kg}$ of TSS, VSS, and COD, respectively (table 2). This resulted in a 2.9 TSS/VSS ratio, much less than the previous two seasons. However, the VSS and COD totals were approximately twice that of the two previous seasons. One possible explanation for the increase could be the disturbance of the grassy approach leading to the debris basin and terrace during pen construction. The compromised grassy approach may have contributed to the previously collected organic material. In addition, the pen surface was relatively new, and not typical of most seasoned pen surfaces.

Discharge water contained 2830, 1520, and $9680 \mathrm{~kg}$ of TSS, VSS, and COD, respectively (table 2). This resulted in a 1.9 TSS/VSS ratio. The discharge TSS total was less than for year 2000, while the VSS total was nearly $50 \%$ greater. The soil used to renovate the pen surfaces was a calcareous subsoil that was dominated by calcium carbonate complexes. These complexes do not settle readily and would pass through to the discharge water. These complexes are volatilized during the $550^{\circ} \mathrm{C}$ of the VSS analysis (Nelson and Sommers, 1994). This increase in inorganic volatile suspended solids appears to be confirmed by examining the COD total for the 1999 and 2001 seasons. The 2001 COD totals were twice the 1999 season totals; however, total runoff volume was nearly twice as great, indicating the oxygen demand was similar.

Runoff TSS concentrations during the 2001 season ranged from $1900 \mathrm{mg} \mathrm{L}^{-1}$ to $7360 \mathrm{mg} \mathrm{L}^{-1}$, while discharge concentrations ranged between 500 and $1500 \mathrm{mg} \mathrm{L}^{-1}$ (fig. 3). There was significant reduction $(\mathrm{p}=0.05)$ between runoff and discharge concentrations for all runoff events. The TSS concentrations were similar to the previous two seasons. Similarly, runoff VSS concentrations ranged from 870 to $2240 \mathrm{mg} \mathrm{L}^{-1}$, while discharge VSS concentrations ranged from 230 to $710 \mathrm{mg} \mathrm{L}^{-1}$ (fig. 4). Volatile suspended solids concentrations were similar to the previous two seasons, with significant reduction between runoff and discharge concentrations for all precipitation events. The runoff COD concentrations ranged from 3970 to $6730 \mathrm{mg} \mathrm{L}^{-1}$ (fig. 5). The effluent COD concentrations ranged from 1440 to $4110 \mathrm{mg}$ $\mathrm{L}^{-1}$ (fig. 5). Chemical oxygen demand concentrations were comparable to the 1999 season, and significantly reduced between the runoff and discharge concentration for all measured events.

\section{Conclusions}

There was an average $80 \%, 67 \%$, and $59 \%$ reduction in contaminants as measured by TSS, VSS, and COD, respectively, as the runoff passed through the debris basin for the three seasons. These solids were retained in the basin and collected annually for application to cropland as a fertilizer amendment. Significant reductions in TSS, VSS, and COD concentration of runoff water were measured for most of the precipitation events.

No water was ever detected exiting the VFS, so the discharge water was effectively used by the hay crop for production. The estimated nitrogen load in the discharge water leaving the basin and entering the vegetative filter strip was equivalent to or less than the total nitrogen removed by the hay crop. This would indicate that the overall runoff control and treatment system was sustainable with respect to total nitrogen discharged from the basin.

The robustness of the passive treatment system was demonstrated during feedlot pen renovation, when significant reductions in VSS and COD concentrations were measured for all events. Similarly, significant reductions in TSS concentrations were measured for all but one event during the 2000 season. Improvements in concentration reduction may have been increased had more attention been placed on reestablishment of the grassy approach following pen renovations.

The ratio of TSS/VSS decreased as the runoff water passed through the system. This would indicate that the debris basin was most effective at removing more dense suspended solids like soil particles. However, more data will have to be collected to evaluate this trend as the pen surface becomes more seasoned following renovations.

\section{ACKNOWLEDGEMENTS}

The authors would like to acknowledge Kimberly Ely for her assistance in data collection and analyses.

\section{REFERENCES}

APHA. 1992. Standard Methods for the Examination of Water and Wastewater. 18th ed. Washington, D.C.: American Public Health Association.

Eigenberg, R. A., R. L. Korthals, J. A. Nienaber, and G. L. Hahn. 1998. Implementation of a mass balance approach to predicting nutrient fate of manure from beef cattle feedlots. Applied Eng. in Agric. 14(5): 475-484.

EPA. 2003. Federal Register 68(29). 40 CFR Parts 9, 122, 123, and 412.

Grant, D. C. 1991. Isco Open Channel Flow Measurement Handbook. Lincoln, Neb.: Isco, Inc.

Hach. 1992. Hach Water Analysis Handbook. 2nd ed. Loveland, Colo.: Hach Company.

Huffman, R. L., and P. W. Westerman. 1995. Estimated seepage losses from established swine waste lagoon in the lower coastal plain of North Carolina. Trans. ASAE 38(2): 449-453.

McCullough, M. C., D. B. Parker, B. W. Auvermann, and C. Robinson. 1999. Investigation of seal formation on the profile. ASAE Paper No. 994081. St. Joseph, Mich.: ASAE.

Mulvaney, R. L. 1996. Nitrogen: Inorganic forms. Chapter 38 in Methods of Soil Analysis: Part 3. Chemical Methods. J. M. Bigham, ed. Madison, Wisc.: SSSA.

Nelson, D. W., and L. E. Sommers. 1994. Total carbon, organic carbon, and organic matter, Chapter 34 in Methods of Soil 
Analysis: Part 3. Chemical Methods, 961-1010. D. L. Sparks, ed. Madison, Wisc.: SSSA, ASA.

Parker, D. B., D. E. Eisenhauer, D. D. Schulte, and D. L. Martin. 1999. Modeling seepage from an unlined beef cattle feedlot runoff storage pond. Trans. ASAE 42(5): 1437-1445.

Westerman, P. W., R. L. Huffman, and J. S. Feng. 1995.

Swine-lagoon seepage in sandy soil. Trans. ASAE 38(6):

$1749-1760$
Woodbury, B. L., J. A. Nienaber, and R. A. Eigenberg. 2002.

Operational evaluation of a passive beef cattle runoff control and treatment system. Applied Eng. in Agric. 18(5): 541-545. 